Published in final edited form as:

J Med Chem. 2016 February 11; 59(3): 925-933. doi:10.1021/acs.jmedchem.5b01354.

\title{
Novobiocin Analogs That Inhibit the MAPK Pathway
}

Jessica A. Hall, Sahithi Seedarala, Huiping Zhao, Gaurav Garg, Suman Ghosh, and Brian S. J. Blagg*

Department of Medicinal Chemistry, The University Of Kansas, 1251 Wescoe Hall Drive, 4070

Malott Hall, Lawrence, KS 66045

\section{Abstract}

Heat shock protein 90 (Hsp90) inhibition by modulation of the N-or C-terminal binding site has become an attractive strategy for the development of anti-cancer chemotherapeutics. The first Hsp90 C-terminus inhibitor, novobiocin, manifested a relatively high IC50 value of $\sim 700 \mu \mathrm{M}$. Therefore, investigation of the novobiocin scaffold has led to analogs with improved antiproliferative activity (nanomolar concentrations) against several cancer cell lines. During these studies, novobiocin analogs that do not inhibit Hsp90 were identified; however, these analogs demonstrated potent anti-proliferative activity. Compound $\mathbf{2}$, a novobiocin analog, was identified as a MAPK pathway signaling disruptor that lacked Hsp90 inhibitory activity. In addition, structural modifications of compound $\mathbf{2}$ were identified that segregated Hsp90 inhibition from MAPK signaling disruption. These studies indicate that compound $\mathbf{2}$ represents a novel scaffold for disruption of MAPK pathway signaling and may serve as a useful structure for the generation of new anti-cancer agents.

\section{Graphical abstract}

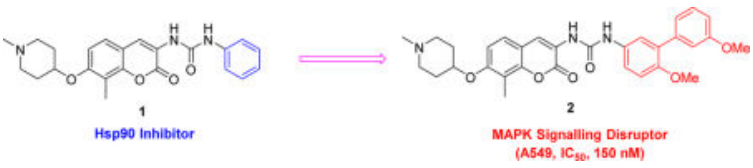

\section{Keywords}

Hsp90; client protein; MAPK signaling pathway; feed-back mechanism; structure-activity relationship

\section{INTRODUCTION}

Heat shock protein 90 (Hsp90) is a molecular chaperone that facilitates the conformational maturation of other cellular proteins, termed clients, via the Hsp90 chaperone cycle. Hsp90 functions as a homodimer and each monomer comprises an $\mathrm{N}$-terminal domain (the site of ATP-binding and hydrolysis), a middle domain, and a C-terminal dimerization domain.

\footnotetext{
“Corresponding Author: Brian S. J. Blagg, Phone: (785) 864-2288, Fax: (785) 864-5326, bblagg@ ku.edu.

Supporting information includes figures and additional experimental information. This information is available free of charge and can be found at http://pubs.acs.org
} 
Inhibitors that target the $\mathrm{N}$-and $\mathrm{C}$-termini of $\mathrm{Hsp} 90$ can halt client maturation and lead to ubiquitinylation and degradation of the substrate via the proteasome ${ }^{1-5}$. N-terminal inhibitors perturb ATPase activity at the N-terminus and include derivatives of the natural product geldanamycin. However, N-terminal inhibition also leads to induction of the prosurvival heat shock response (HSR) via Heat Shock Factor-1. This led to the development of C-terminal inhibitors, in which the HSR is avoided and client degradation is maintained. There are several therapeutic opportunities for small molecules that target the Hsp90 N-or Cterminus, including the development of anticancer chemotherapeutics ${ }^{6-20}$.

Novobiocin is a natural product that inhibits the Hsp90 C-terminus and was found to exhibit an IC50 value of $\sim 700 \mu \mathrm{M}$ against the SKBr3 breast cancer cell line (Figure 1) ${ }^{21}$. Extensive structure-activity relationship (SAR) studies on novobiocin have greatly improved antiproliferative activity against many different cancer cell lines and identified structural elements necessary for Hsp90 inhibition; however, exploration of the amide linker has yet to be fully investigated ${ }^{22-40}$.

During SAR studies of the urea linker that was probed as a surrogate for the amide, analogues were identified that exhibited potent anti-proliferative activity against several cancer cell lines. However, some of the compounds did not inhibit Hsp90. Investigation of these analogues led to identification of $\mathbf{2}$, a novobiocin analogue that exhibited potent antiproliferative activity against the MCF7 breast and A549 lung cancer cell lines without Hsp90 inhibitory activity. Instead, compound 2 was shown to disrupt mitogen-activated protein kinase (MAPK) signaling and in a time-dependent manner inhibited the phosphorylation of MEK and ERK. Since oncogenic mutations frequently occur within the MAPK pathway, much research has been devoted to the development of inhibitors of this pathway, including EGFR, Raf, MEK and ERK ${ }^{41-43}$. Preliminary SAR studies of 2 examined the necessity of each methoxy substitution on the biaryl side chain and identified moieties that transition novobiocin analogues from Hsp90 inhibitory activity, such as compound 1, to MAPK pathway inhibitors (Figure 1).

\section{RESULT AND DISCUSSION}

As shown in Scheme 1, compound $\mathbf{1}$ was prepared in one step by coupling the previously reported aniline $6^{39}$ with the commercially available phenylisocyanate, 7a. Compound $\mathbf{2}$ was synthesized from biaryl acid $\mathbf{8}^{39}$, using diphenylphosphorylazide to give the corresponding azide, which underwent Curtius rearrangement to afford phenylisocyanate, $\mathbf{7 b}$. Subsequent coupling of $\mathbf{7 b}$ with intermediate $\mathbf{6}$, provided compound $\mathbf{2}$ in good yield.

Many client proteins that depend upon Hsp90 are up-regulated and oftentimes represent signaling pathways that are hijacked during malignant transformation ${ }^{16,18,44,45}$. Compounds that inhibit Hsp90, or the Hsp90 chaperone cycle, lead to client protein degradation via the ubiquitin proteasome pathway and deprive cancer the use of clients that drive progression and growth ${ }^{1,4,5,46}$. Therefore, decreased client protein levels are observed at the IC50 values obtained in cell proliferation assays for Hsp90 inhibitors. To determine whether a compound inhibits Hsp90, IC50 values are generated against cancer cell lines that depend upon functional Hsp90. The estrogen receptor-expressing MCF7 breast cancer cell line and the 
KRAS-driven A549 lung cancer cell line both depend upon Hsp90 for client protein maturation. Therefore, compounds that exhibit potent anti-proliferative activity against these cell lines may inhibit Hsp90. Table 1 shows the IC50 values for compounds $\mathbf{1}$ and $\mathbf{2}$ generated against these cancer cell lines, as well as the normalized cell line, MRC-5. 1 and 2 were shown to exhibit potent inhibition of cancer cell growth compared to the MRC-5 line, indicating the cellular target(s) for these compounds facilitate cancer growth.

Client protein levels in MCF7 and A549 cells were determined via Western blot analysis after incubation with low and high concentrations of $\mathbf{1}$ and $\mathbf{2}\left(\mathrm{L}=\right.$ half the $\mathrm{IC}_{50}$ value; $\mathrm{H}=$ five-times the $\mathrm{IC}_{50}$ value, respectively; Figure 2). If client levels are unaffected upon incubation with low concentrations of the compound and decreased at high concentrations, the compound is likely to inhibit Hsp90 function.

Incubation with high concentrations of $\mathbf{1}$ led to decreased levels of the Hsp90-dependent clients EGFR, Her2 and C-Raf in both MCF7 and A549 cell lysates, when compared to vehicle control (Figure 2). Hsp90 levels at low and high concentrations of 1 were comparable to vehicle and indicative of Hsp90 C-terminal inhibition ${ }^{37}$. Furthermore, incubation with the $\mathrm{N}$-terminal inhibitor, geldanamycin (GDA), led to decreased client levels at concentrations that increased cellular levels of Hsp90 (Supplementary Figure 1) 47,48. $^{\text {. }}$ These data suggest the mechanism of action manifested by compound $\mathbf{1}$ is inhibition of the Hsp90 C-terminus, as opposed to N-terminal inhibition.

In contrast, client protein levels were unchanged after incubation with low and high concentrations of $\mathbf{2}$ against both MCF7 and A549 cells. Since no Hsp90-dependent client protein degradation was observed with compound $\mathbf{2}$, the data suggests this compound inhibits cancer cell growth unrelated to Hsp90 inhibition. The luciferase refolding activity was measured for the compound $\mathbf{2}$ to confirm whether this compound has Hsp90 inhibitory activity. The data demonstrates that compound $\mathbf{2}$ does not inhibit the re-maturation of firefly luciferase, similar to DMSO treated cells (Figure 2). In contrast, the novobiocin analog, KU-257, which inhibits Hsp90 ${ }^{39}$, was shown to inhibit luciferase re-maturation (Figure 2). These results further confirm that compound 2 inhibits cancer cell growth unrelated to Hsp90 inhibition. Given the potent antiproliferative activity manifested by $\mathbf{2}$ against both cancer cell lines as well as the selective inhibition of cancer cell growth, the mechanism by which $\mathbf{2}$ manifests this anti-cancer activity was pursued.

Since 2 exhibited potent anti-proliferative activity against the non-small cell lung cancer cell line A549 and generated an IC50 value of $0.15 \pm 0.02 \mu \mathrm{M}$, subsequent studies were initiated with this cell line. The A549 cell line expresses wild type B-Raf, C-Raf and mutant KRAS. Proliferation of the A549 cell line is driven by over-activation/expression of proteins involved in the Ras-Raf-MEK-ERK (MAPK) pathway and consequently, this cell line is commonly utilized to identify small molecule kinase inhibitors that target Raf, MEK and/or $\mathrm{ERK}^{49}$. Interestingly, many inhibitors that target kinases involved in the MAPK pathway display structural similarities to compound 2 (Figure 3).

Given the potent anti-proliferative activity exhibited by $\mathbf{2}$ against the MAPK-driven A549 cancer cell line, and the structural similarities between $\mathbf{2}$ and known disruptors of this 
pathway, it was hypothesized that 2 may inhibit the A549 cancer growth through disruption of MAPK signaling. Therefore, to determine whether $\mathbf{2}$ inhibits kinases within the MAPK pathway, Western blots for phosphorylated proteins involved in the MAPK pathway were performed using A549 lysates treated with 2 at $750 \mathrm{nM}$ (five-times the IC50 value) for two to 12 hours (Figure 4A). Treatment with 2 led to a time-dependent decrease in phosphorylated MEK and ERK suggesting this compound inhibits kinase activity; however, decreased levels of phospho-MEK (p-MEK) and phospho-ERK (p-ERK) were observed at different incubation times. Decreased p-MEK levels occurred after four hours of incubation with 2 and were undetectable after 12 hour incubation. In contrast, decreased p-ERK levels were only observed after six hours of incubation and continued to decrease during the 12 hour incubation. These data indicate that $\mathbf{2}$ disrupts kinase activity upstream of MEK and ERK; 2 prevented phosphorylation of MEK, which subsequently prevented phosphorylation of ERK. The levels of other proteins crucial for MAPK signaling, such as EGFR and C-Raf, remained constant at each time point and were comparable to vehicle control. C-Raf is an Hsp90 client and undergoes proteolytic degradation upon 12 hours of incubation with Hsp90 inhibitors. After 12 hours of incubation with 2, C-Raf levels were similar to vehicle and remained constant at each time point, which demonstrates that compound $\mathbf{2}$ inhibits cancer cell growth by a mechanism unrelated to Hsp90 inhibition. Total MEK and ERK levels also remained constant at each time point and were comparable to vehicle, indicating that decreased p-MEK and p-ERK levels were not the result of decreased MEK and ERK levels. To determine whether $\mathbf{2}$ inhibits general kinase activity, Western blots were generated for phosphorylated Akt (p-Akt) and total Akt levels using A549 cell lysates after two to 12 hours of incubation. Akt is phosphorylated by phosphoinositide 3-kinase (PI3K), and p-Akt formation is unrelated to the MAPK pathway ${ }^{50}$. Supplementary Figure 2 demonstrates that p-Akt and total Akt levels were unaffected at each time point, which suggests that 2 preferentially inhibits phosphorylation of the MAPK pathway proteins.

Figure 4B shows a concentration-dependent decrease in p-MEK and p-ERK after 12 hours of incubation with 2 . A low concentration of 2 (L; half the IC50 value, $70 \mathrm{nM}$ ) had little effect on cellular levels of p-MEK and p-ERK; however, incubation with a high concentration of 2 (five-times the IC50 value, $750 \mathrm{nM}$ ) resulted in significantly lower levels of p-MEK and pERK, which were consistent with previous observations. Little effect was observed on the levels of other MAPK-associated proteins, as well as total MEK and ERK levels at either concentration.

It is well established that small molecule inhibition of the MAPK pathway activates multiple feed-back mechanisms that ultimately result in up-regulated MAPK pathway activity ${ }^{51-54}$. In vitro, this occurs at short incubation times and can be observed up to 24 hours after incubation with inhibitors of the MAPK pathway (via increased levels of p-MEK and p-ERK as well as increased transcription of MAPK proteins and proteins that support feed-back mechanisms). Western blot analysis of MAPK pathway proteins, p-MEK and p-ERK from A549 cell lysates treated with high concentrations of $2(750 \mathrm{nM})$ for 12 and 24 hours were conducted (Figure 4B). After 24 hours of incubation, p-MEK and p-ERK levels were only slightly increased compared to 12 hours of incubation; however, these levels remained lower than vehicle control, which could result from the up-regulation of MAPK pathway activity 
via a feed-back mechanism or the consequence of compound $\mathbf{2}$ instability, which may produce metabolites that no longer interact with the cellular target(s).

To determine whether re-establishment of detectable p-MEK and p-ERK levels after 24 hours of incubation with $\mathbf{2}$ was the result of feed-back mechanism activation, Western blots for Her3 and wild-type B-Raf levels were performed. Her3 and wild type B-Raf are expressed at relatively low levels in cancer cells under normal conditions. However, inhibition of MAPK pathway activity via small molecule EGFR, Raf or MEK inhibitors induce Her3 and wild-type B-Raf overexpression to compensate for decreased p-MEK and p-ERK signaling. After 24 hours of incubation with 2, Her3 and wild-type B-Raf levels were comparable to vehicle and indicated no activation of a feed-back mechanism (Figure 5). Western blots for Her3 and wild-type B-Raf levels from A549 lysates treated with control compounds (sorafenib, vemurafenib and TAK-632) for 12 and 24 hours were also performed (Figure 5). Sorafenib is a kinase inhibitor and incubation with sorafenib at five-times the reported IC50 value $(14 \mu \mathrm{M})$ resulted in decreased p-MEK and p-ERK levels and a timedependent increase in Her3 levels (Supplementary Figure 3; Figure 5) ${ }^{49}$. Vemurafenib and TAK-632 are Raf inhibitors. Vemurafenib is a mutant B-Raf inhibitor that is relatively inactive against the A549 cell line, which expresses only wild-type B-Raf. Incubation with a high concentration of vemurafenib (five-times the reported IC50 value against the A549 cancer cell line, $>50 \mu \mathrm{M}$ ) had little effect on Her3 and wild-type B-Raf levels, as well as MAPK pathway signaling after 12 and 24 hours (Figure 5; Supplementary Figure 3) ${ }^{55}$. TAK-632 is a kinase inhibitor that preferentially inhibits wild-type B-Raf and C-Raf, and ultimately leads to decreased p-MEK and p-ERK levels (Supplementary Figure 3). Her3 and wild-type B-Raf levels remained unaffected after 12 and 24 hours of incubation with TAK-632 at five-times the reported IC50 value $(8.5 \mu \mathrm{M})$ which is comparable to 2 (Figure $5)^{56}$. These data indicate that 2 prevents p-MEK and p-ERK formation via a mechanism similar to TAK-632, which targets wild-type B-Raf and C-Raf.

It has been previously reported that Raf inhibitor treatment leads to hetero-dimerization between wild type B-Raf and c-Raf causing re-establishment of MAPK pathway signaling and cancer proliferation ${ }^{57}$. Therefore, a co-immunoprecipitation assay was performed to investigate whether compound $\mathbf{2}$ activates the MAPK pathway by heterodimer formation. The results provided in Figure 6 demonstrate that $\mathbf{2}$ does not result in dimerization of wild type B-Raf and c-Raf.

In lieu of the biaryl side chain, the incorporation of a phenyl ring onto the urea linker (1) results in Hsp90 inhibition as observed via client protein degradation (see Figure 2), while replacement of the phenyl substituent with a bulky di-methoxy biaryl side chain leads to disruption of the MAPK pathway. Therefore, compounds $3, \mathbf{4}$ and $\mathbf{5}$, which contain substitutions about the biaryl side chain were synthesized to identify substitutions that distinguish Hsp90 inhibitory activity from MAPK pathway inhibition (Scheme 2). Compound $\mathbf{3}$ contains a biaryl side chain with no methoxy groups, while $\mathbf{4}$ and $\mathbf{5}$ each contain a single methoxy substitution on the biaryl side chain. IC50 values for each compound were determined against the A549 cancer cell line as shown in Table 2. Each compound exhibited potent anti-proliferative activity within the nanomolar concentration range. 
Western blot analyses for Hsp90 clients were performed using A549 cell lysates dosed for 12 and 24 hours with high concentrations of each compound (five-times the IC50 value) to identify Hsp90 inhibitors (Figure 7A). After 24 hours of incubation with 3, decreased levels of Hsp90-dependent client proteins were observed while constant levels of Hsp90 remained, suggesting that $\mathbf{3}$ is an Hsp90 C-terminal inhibitor. Single methoxy substitutions on the biaryl side chain (4 and 5) did not result in decreased client levels after 12 or 24 hours of incubation, indicating no Hsp90 inhibition. Western blot analyses for MAPK pathway proteins and p-MEK and p-ERK levels were performed using the A549 cell lysates dosed for 12 and 24 hours with $\mathbf{4}$ and $\mathbf{5}$ and are shown in Figure 7B. 12 hours of incubation with 4 led to decreased p-MEK and pERK levels compared to vehicle; however in contrast to $\mathbf{2}$, pMEK and p-ERK levels were reestablished after 24 hours of incubation with 4 and $\mathbf{5}$. P-ERK levels were also decreased after 12 hours of incubation with 5; however, 24 hours of incubation resulted in p-ERK levels that were comparable to vehicle. After 12 and 24 hours of incubation with $\mathbf{5}$, p-MEK levels were unchanged.

These data indicate that both methoxy substitutions on the biaryl side chain are important for prolonged MAPK pathway disruption. While mono-methoxy substitutions inhibited p-MEK and/or p-ERK formation, neither substitution alone was able to sustain inhibitory activity to the extent of the dimethoxy-substituted side chain present in $\mathbf{2}$.

\section{CONCLUSIONS}

In conclusion, 2 was synthesized during SAR studies of novobiocin-based Hsp90 C-terminal inhibitors that contain urea surrogates of the amide linker. 1 was identified as an Hsp90 inhibitor via Hsp90-dependent client degradation, however, 2 failed to exhibit Hsp90 inhibitory activity. Upon further investigation, 2 was shown to disrupt the MAPK pathway signaling by preventing p-MEK formation after 4 hours of incubation, which ultimately disrupted p-ERK formation. Disruption of p-MEK and p-ERK formation was comparable to the control compound TAK-632, a Raf inhibitor that preferentially inhibits wild type B-Raf and C-Raf; however, 2 exerted this activity at one tenth the IC50 value of TAK-632 (IC50 value of $0.15 \pm 0.02 \mu \mathrm{M}$ versus $1.7 \mu \mathrm{M}$ against the A549 lunger cancer cell line). While individual methoxy substitutions on the biaryl side chain inhibit p-MEK and/or p-ERK formation, the dimethoxy-substituted biaryl sidechain is required for sustained inhibition. Therefore, $\mathbf{2}$ represents a novel, novobiocin-based scaffold for the development of MAPK pathway inhibitors and appears to manifest a similar mechanism of action to TAK-632 and target C-Raf and wild-type B-Raf.

\section{EXPERIMENTAL SECTION}

\section{Chemistry}

General Methods- ${ }^{1} \mathrm{HNMR}$ were recorded at 400 or $500 \mathrm{MHz}$ (Bruker DRX-400 Bruker with a H/C/P/F QNP gradient probe) spectrometer and ${ }^{13} \mathrm{C}$ NMR spectra were recorded at 100 or $125 \mathrm{MHz}$ (Bruker DRX 500 with broadband, inverse triple resonance, and high resolution magic angle spinning HR-MA probe spectrometer); chemical shifts are reported in $\delta(\mathrm{ppm})$ relative to the internal reference chloroform- $d(\mathrm{CDQ} 3,7.27 \mathrm{ppm})$ or dimethyl sulfoxide- $d_{6}\left(\right.$ DMSO- $\left.\mathrm{d}_{6}, 2.50 \mathrm{ppm}\right)$. High resolution mass spectra $(\mathrm{FAB})$ were recorded with 
a LCT Premier (Waters Corp., Milford, MA) spectrometer. The purity of all compounds was determined to be $>95 \%$ as determined by HPLC analysis. TLC was performed on glassbacked silica gel plates (Uniplate) with spots visualized by UV light. All solvents were reagent grade and when necessary, were purified and dried by standard methods.

Concentration of solvents occurred via the use of a rotary evaporator operating at reduced pressure.

General procedure for the synthesis of urea derivatives: 1-(8-methyl-7-((1methylpiperidin-4-yl)oxy)-2-oxo-2H-chromen-3-yl)-3-phenylurea (1) Phenyl isocyanate (17 $\mathrm{mg}, 0.14 \mathrm{mmol})$ was added to a solution of amine $6^{39}(20 \mathrm{mg}, 0.07 \mathrm{mmol})$ in dichloromethane $(2 \mathrm{~mL})$ and stirred at r.t. overnight. The resulting mixture was concentrated and purified via column chromatography $\left(\mathrm{SiO}_{2}, 10: 1 \mathrm{CH}_{2} \mathrm{Cl}_{2}\right.$ : methanol) to afford 1 as a light brown amorphous solid (22 mg, $78 \%):{ }^{1} \mathrm{H}$ NMR $\left(400 \mathrm{MHz}, \mathrm{CDQ}_{3}\right) \delta 8.75(\mathrm{~s}, 1 \mathrm{H}$, $\mathrm{NH}), 8.52(\mathrm{~s}, 1 \mathrm{H}, \mathrm{NH}), 8.42(\mathrm{~s}, 1 \mathrm{H}), 7.54(\mathrm{~d}, J=7.7 \mathrm{~Hz}, 2 \mathrm{H}), 7.23-7.12(\mathrm{~m}, 3 \mathrm{H}), 6.93(\mathrm{t}, J$ $=7.3 \mathrm{~Hz}, 1 \mathrm{H}), 6.80(\mathrm{~d}, J=8.8 \mathrm{~Hz}, 1 \mathrm{H}), 4.39(\mathrm{~m}, 1 \mathrm{H}), 2.70 \sim 2.62(\mathrm{~m}, 1 \mathrm{H}), 2.40 \sim 2.33(\mathrm{~m}$, $2 \mathrm{H}), 2.32(\mathrm{~s}, 3 \mathrm{H}), 2.32(\mathrm{~s}, 3 \mathrm{H}), 2.06-1.82(\mathrm{~m}, 2 \mathrm{H}), 1.90 \sim 1.88(\mathrm{~m}, 2 \mathrm{H}) .{ }^{13} \mathrm{C} \mathrm{NMR}(126$ MHz, DMSO) $\delta 158.31,155.48,152.28,148.17,139.27,128.93,125.25,122.61,122.21$,

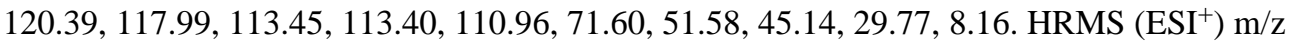
$\left[\mathrm{M}+\mathrm{H}^{+}\right]$calcd for $\mathrm{C}_{23} \mathrm{H}_{26} \mathrm{~N}_{3} \mathrm{O}_{4} 408.1923$; found 408.1919 .

1-(3',6-dimethoxy-[1,1' -biphenyl]-3-yl)-3-(8-methyl-7-((1-methylpiperidin-4-yl)oxy)-2oxo-2H-chromen-3-yl)urea (2) Compound 2 was obtained as a white amorphous solid (15 $\mathrm{mg}, 82 \%):{ }^{1} \mathrm{H}$ NMR $\left(500 \mathrm{MHz}, \mathrm{CDCl}_{3}+\mathrm{CH}_{3} \mathrm{OH}\right) \delta 8.26(\mathrm{~s}, 1 \mathrm{H}), 7.33-7.29(\mathrm{~m}, 2 \mathrm{H}), 7.19$ $-7.14(\mathrm{~m}, 2 \mathrm{H}), 6.97-6.95(\mathrm{~m}, 2 \mathrm{H}), 6.82(\mathrm{~d}, J=8.8 \mathrm{~Hz}, 1 \mathrm{H}), 6.74(\mathrm{~d}, J=8.1 \mathrm{~Hz}, 2 \mathrm{H}), 4.39$ $(\mathrm{m}, 1 \mathrm{H}), 3.70(\mathrm{~s}, 3 \mathrm{H}), 3.65(\mathrm{~s}, 3 \mathrm{H}), 2.60(\mathrm{~m}, 2 \mathrm{H}), 2.40(\mathrm{~m}, 2 \mathrm{H}), 2.25(\mathrm{~s}, 3 \mathrm{H}), 2.17(\mathrm{~s}, 3 \mathrm{H})$, $1.91(\mathrm{~m}, 2 \mathrm{H}), 1.81(\mathrm{~m}, 2 \mathrm{H}) .{ }^{13} \mathrm{C} \mathrm{NMR}\left(126 \mathrm{MHz}, \mathrm{CDQ}_{3}+\mathrm{CH}_{3} \mathrm{OH}\right) \delta 159.62,159.02$, $155.78,153.52$, 152.56, 148.66, 139.45, 131.64, 130.85, 128.82, 124.95, 122.57, 122.49, 121.91, 121.75, 120.06, 115.08, 114.68, 113.90, 112.45, 111.94, 110.44, 55.79, 55.04, 51.66, 45.41, 29.78, 7.97. HRMS $\left(\mathrm{ESI}^{+}\right) \mathrm{m} / \mathrm{z}\left[\mathrm{M}+\mathrm{H}^{+}\right]$calcd for $\mathrm{C}_{3} \mathrm{iH}_{34} \mathrm{~N}_{3} \mathrm{O}_{6} 544.2448$; found 544.2443 .

1-([1,1' -biphenyl]-3-yl)-3-(8-methyl-7-((1-methylpiperidin-4-yl)oxy)-2-oxo-2H-chromen-3yl)urea (3) Compound 3 was obtained as a brown amorphous solid (27 mg, 76\%): ${ }^{1} \mathrm{H}$ NMR (500 MHz, DMSO) $\delta 9.60(\mathrm{~s}, 1 \mathrm{H}, \mathrm{NH}), 8.73(\mathrm{~s}, 1 \mathrm{H}, \mathrm{NH}), 8.44(\mathrm{~s}, 1 \mathrm{H}), 7.88(\mathrm{~s}, 1 \mathrm{H}), 7.65-$ $7.61(\mathrm{dd}, J=8.3,1.1 \mathrm{~Hz}, 2 \mathrm{H}), 7.52-7.47(\mathrm{~m}, 2 \mathrm{H}), 7.42-7.37(\mathrm{~m}, 2 \mathrm{H}), 7.36-7.32(\mathrm{~m}$, $1 \mathrm{H}), 7.31-7.27$ (dt, $J=7.6,1.3 \mathrm{~Hz}, 1 \mathrm{H}), 7.11-7.06$ (d, $J=8.9 \mathrm{~Hz}, 1 \mathrm{H}) .4 .54(\mathrm{~m}, 1 \mathrm{H}), 2.59$ $(\mathrm{m}, 2 \mathrm{H}), 2.31(\mathrm{~m}, 2 \mathrm{H}), 2.23(\mathrm{~s}, 3 \mathrm{H}), 2.22(\mathrm{~s}, 3 \mathrm{H}), 1.95(\mathrm{~m}, 2 \mathrm{H}), 1.73(\mathrm{~m}, 2 \mathrm{H}) .{ }^{13} \mathrm{C}$ NMR (126 MHz, DMSO) 5 158.29, 155.55, 152.31, 148.14, 140.93, 140.19, 139.81, 129.48, 128.93, 127.54, 126.61, 125.21,122.46, 120.62, 120.49, 117.04, 116.17, 113.35, 113.28, $110.93,72.06,51.83,45.66,30.23,8.09$. HRMS $\left(\mathrm{ESI}^{+}\right) \mathrm{m} / \mathrm{z}\left[\mathrm{M}+\mathrm{H}^{+}\right]$calcd for $\mathrm{C}_{29} \mathrm{H}_{30} \mathrm{~N}_{3} \mathrm{O}_{4}$ 484.2236; found 484.2232.

1-(6-methoxy-[1,1'-biphenyl]-3-yl)-3-(8-methyl-7-((1-methylpiperidin-4-yl)oxy)-2-oxo-2Hchromen-3-yl)urea (4) Compound 4 was obtained as a white amorphous solid $(22 \mathrm{mg}$, 71\%): ${ }^{1} \mathrm{H}$ NMR $\left(500 \mathrm{MHz}, \mathrm{CDCl}_{3}\right) \delta 8.60(\mathrm{~s}, 1 \mathrm{H}), 8.43(\mathrm{~s}$, broad, $2 \mathrm{H}, \mathrm{NH}), 7.60(\mathrm{dd}, J=$ $8.8,2.6 \mathrm{~Hz}, 1 \mathrm{H}), 7.55-7.50(\mathrm{~m}, 3 \mathrm{H}), 7.39(\mathrm{t}, J=7.5 \mathrm{~Hz}, 2 \mathrm{H}), 7.35-7.31(\mathrm{~m}, 1 \mathrm{H}), 7.25(\mathrm{~d}$, 
$J=8.6 \mathrm{~Hz}, 1 \mathrm{H}), 6.93(\mathrm{~d}, J=8.9 \mathrm{~Hz}, 1 \mathrm{H}), 6.83(\mathrm{~d}, J=8.8 \mathrm{~Hz}, 1 \mathrm{H}), 4.42(\mathrm{~m}, 1 \mathrm{H}), 3.79(\mathrm{~s}$, $3 \mathrm{H}), 2.68(\mathrm{~m}, 2 \mathrm{H}), 2.42(\mathrm{~m}, 2 \mathrm{H}), 2.38(\mathrm{~s}, 3 \mathrm{H}), 2.09(\mathrm{~s}, 3 \mathrm{H}), 2.04(\mathrm{~m}, 2 \mathrm{H}), 1.91(\mathrm{~m}, 2 \mathrm{H}) .{ }^{13} \mathrm{C}$ NMR (126 MHz, CDQ3+CH3OH) $\delta 159.65,155.85,153.56,152.57,148.66,138.05$, $131.68,131.04,129.29,127.81,126.87,124.91,122.60,122.43,121.77,119.91,114.68$, $113.83,111.90,110.45,71.37,55.75,51.76,45.52,29.90,7.96 . \mathrm{HRMS}\left(\mathrm{ESI}^{+}\right) \mathrm{m} / \mathrm{z}\left[\mathrm{M}+\mathrm{H}^{+}\right]$ calcd for $\mathrm{C}_{30} \mathrm{H}_{32} \mathrm{~N}_{3} \mathrm{O}_{5} 514.2342$; found 514.2339.

1-(3'-methoxy-[1,1' -biphenyl]-3-yl)-3-(8-methyl-7-((1-methylpiperidin-4-yl)oxy)-2oxo-2H-chromen-3-yl)urea (5) Compound 5 was obtained as a brown amorphous solid (15 $\mathrm{mg}, 76 \%):{ }^{1} \mathrm{H}$ NMR (500 MHz, DMSO) $\delta 9.59(\mathrm{~s}, 1 \mathrm{H}, \mathrm{NH}), 8.73(\mathrm{~s}, 1 \mathrm{H}, \mathrm{NH}), 8.44(\mathrm{~s}, 1 \mathrm{H})$, $7.84(\mathrm{~s}, 1 \mathrm{H}), 7.52-7.49$ (d, $J=8.6 \mathrm{~Hz}, 1 \mathrm{H}), 7.43-7.35(\mathrm{~m}, 3 \mathrm{H}), 7.32-7.28$ (dt, $J=7.0$, $1.8 \mathrm{~Hz}, 1 \mathrm{H}), 7.22-7.18(\mathrm{~m}, 1 \mathrm{H}), 7.16-7.13(\mathrm{t}, J=2.1 \mathrm{~Hz}, 1 \mathrm{H}), 7.11-7.07(\mathrm{~d}, J=8.9 \mathrm{~Hz}$, $1 \mathrm{H}), 6.99-6.94(\mathrm{dd}, J=8.2,2.5 \mathrm{~Hz}, 1 \mathrm{H}), 4.55(\mathrm{~m}, 1 \mathrm{H}), 3.83(\mathrm{~s}, 3 \mathrm{H}), 2.60(\mathrm{~m}, 2 \mathrm{H}), 2.33(\mathrm{~m}$, 2H), 2.24 (s, 3H), 2.23 (s, 3H), 1.96 1.92 (m, 2H), 1.73 1.72 (m, 2H). ${ }^{13} \mathrm{C}$ NMR (126 MHz, DMSO) $\delta 159.66,158.29,155.54,152.30,148.15,141.71,140.80,139.74,130.00,129.43$, 125.23, 122.46, 120.73, 120.50, 118.95, 117.19, 116.27, 113.36, 113.29, 112.95, 112.24, 110.93, 71.99, 55.10, 51.80, 45.60, 30.17, 8.10. HRMS $\left(\mathrm{ESI}^{+}\right) \mathrm{m} / \mathrm{z}\left[\mathrm{M}+\mathrm{H}^{+}\right]$calcd for $\mathrm{C}_{30} \mathrm{H}_{32} \mathrm{~N}_{3} \mathrm{O}_{5}$ 514.2342; found 514.2346.

\section{Biology}

Antibodies and Reagents: Antibodies targeting Akt 1/2/3 and actin were purchased from Santa Cruz Biotechnology. The antibody targeting Hsp90 was purchased from Thermo Scientific (PA3-013). The following antibodies were purchased from Cell Signaling: EGF Receptor, p44/42 MAPK, P-p44/42 MAPK, MEK1/2, P-MEK1/2, pAkt, BRaf, CRaf, Her3/ ErbB3 and Her2/ErbB2. Geldanamycin was purchased from Sigma Aldrich and sorafinib, vemurafinib and TAK-632 were purchased from Selleckchem.

Cell Culture: the media for each cell line was supplemented with streptomycin $(500 \mu \mathrm{g} / \mathrm{mL})$, penicillin (100 units $/ \mathrm{mL}$ ), and 10\% FBS. MCF7 cells were maintained in Advanced DMEM/F12 (1:1; Gibco) supplemented with L-glutamine ( $2 \mathrm{mM})$. A549 cells were maintained in F12K (Cellgro). MRC-5 cells were maintained in DMEM (Cellgro). Cells were grown in a humidified atmosphere $\left(37^{\circ} \mathrm{C}, 5 \% \mathrm{CO} 2\right)$ and passaged when confluent.

Anti-proliferation: cells were grown to confluence, seeded ( 2000 cells/well, $100 \mu \mathrm{L}$ total media) in clear, flat-bottom 96-well plates and allowed to attach overnight. Compound at varying concentrations in DMSO (1\% DMSO final concentration) was added. Cells were returned to the incubator for an additional $72 \mathrm{~h}$. After $72 \mathrm{~h}$, cell growth was determined using an MTS/PMS cell proliferation kit (Promega) per the manufacturer's instructions. Cells that incubated in $1 \%$ DMSO were used as $100 \%$ proliferation (i.e. DMSO $=100 \%$ growth) and the relative growth for each compound concentration was compared to $1 \%$ DMSO. IC50 values were calculated from two separate experiments performed in triplicate using GraphPad Prism 6.0.

Western Blot: cells were grown to confluence and seeded at $0.4 \times 106$ cells/well $/ 2 \mathrm{~mL}$. Cells were incubated for 24 hours and treated with compound in DMSO $(0.25 \%$ DMSO final concentration), or vehicle (DMSO) for the indicated amount of time. Cells were harvested in 
cold PBS and lysed using MPER (Thermo Scientific) supplemented with protease and phosphatase inhibitors (Roche) according to manufacturer's directions. Lysates were clarified at $14,000 \mathrm{~g}$ for 15 minutes at $4^{\circ} \mathrm{C}$. Protein concentrations were determined using the Pierce BCA protein assay kit per the manufacturer's instructions. Equal amounts of protein $(15 \mu \mathrm{g})$ were electrophoresed under reducing conditions (10\% acrylamide gels), transferred to PVDF, and immunoblotted with the corresponding antibody. Membranes were incubated with an appropriate horseradish peroxidase-labeled secondary antibody, developed with a chemiluminescent substrate, and visualized.

Co-immunoprecipitation: A549 cell lines were plated in $10 \mathrm{~cm}$ cell culture dishes or T25 flasks and allowed to grow to $\sim 80 \%$ confluency. A549 cell lines were received DMSO $(0.1 \%)$ (Vehicle), or the indicated drugs dissolved in DMSO at indicated concentrations for $24 \mathrm{~h}$. After drug treatments A549 cell lines were harvested in lysis buffer containing $0.1 \%$ NP40, $50 \mathrm{mM}$ Tris (pH 7.5), $150 \mathrm{mM} \mathrm{NaCl}$, protease and phosphatase inhibitor cocktails (Roche). Lysates were clarified and protein concentration was determined using BCA assay. For co-immunoprecipitation, $500 \mu \mathrm{g}$ of total protein was diluted to $500 \mu \mathrm{L}$ total volume in lysis buffer and incubated with $10 \mu \mathrm{l}$ of primary antibody overnight at $4{ }^{\circ} \mathrm{C}$ with rocking. Immune complexes were captured with $30 \mu \mathrm{L}$ of DynaBeads Protein $\mathrm{G}$ (Invitrogen) for $3 \mathrm{~h}$ with rocking at $4{ }^{\circ} \mathrm{C}$. Protein $\mathrm{G}$ Bead complexes were washed three times with lysis buffer and eluted with sample buffer. Samples were then boiled and subjected to SDS-PAGE and Western blot analysis.

Luciferase Refolding Assay: Compound at varying concentrations in DMSO (1\% DMSO final concentration) was added to wells of a white, round-bottom 96-well plate containing 50 $\mu \mathrm{L}$ of DMEM media. Luciferase-expressing PC3-MM2 cells were grown to confluence, collected, and incubated for 8-12 min at $50{ }^{\circ} \mathrm{C}$ in pre-warmed DMEM media until bioluminescence of luciferase was reduced to $1 \%$ of the initial counts. Cells were added $(60,000$ cells $/ 50 \mu \mathrm{L}$ ) to wells (final concentration of 60,000 cells $/ 100 \mu \mathrm{L}$ ), and the plate was returned to the incubator for $1 \mathrm{~h}$. After $1 \mathrm{~h}, 100 \mu \mathrm{L}$ of luciferase substrate reagent $(75 \mathrm{mM}$ tricine at pH7.8, $24 \mathrm{mM} \mathrm{MgSO}_{4}, 0.3 \mathrm{mM}$ EDTA, $2 \mathrm{mM}$ DTT, 0.313 D-luciferin, $0.64 \mathrm{mM}$ coenzyme A, $0.66 \mathrm{mM}$ ATP, $150 \mathrm{mM} \mathrm{KCl}, 10 \%$ Triton-X, 20\% glycerol, and 3.5\% DMSO) was added to wells, and the bioluminescence was immediately read ( $0.5 \mathrm{~s}$ integration time). Cells that were incubated in $1 \%$ DMSO were used as $100 \%$ bioluminescence (i.e., DMSO = $100 \%$ refolding), and the relative refolding for each compound concentration was compared to that in $1 \%$ DMSO. The concentrations for each compound were in triplicate, and doseresponse curves were generated using GraphPad Prism 5.0.

\section{Supplementary Material}

Refer to Web version on PubMed Central for supplementary material.

\section{Acknowledgments}

We would like to thank Dr. Daniel L. Flynn for his insights and assistance throughout this project.

Funding Source

This work was supported by the NIH grant CA120458 and CA167079. 


\section{References}

1. Bagatell R, Khan O, Paine-Murrieta G, Taylor CW, Akinaga S, Whitesell L. Destabilization of Steroid Receptors by Heat Shock Protein 90-binding Drugs A Ligandindependent Approach to Hormonal Therapy of Breast Cancer. Clin Cancer Res. 2001; 7:2076-2084. [PubMed: 11448926]

2. Connell P, Ballinger CA, Jiang J, Wu Y, Thompson LJ, Hohfeld J, Patterson C. The co-chaperone CHIP regulates protein triage decisions mediated by heat-shock proteins. Nat Cell Biol. 2001; 3:9396. [PubMed: 11146632]

3. Kundrat L, Regan L. Balance between folding and degradation for Hsp90-dependent client proteins: a key role for CHIP. Biochemistry. 2010; 49:7428-7438. [PubMed: 20704274]

4. Murata S, Minami Y, Minami M, Chiba T, Tanaka K. CHIP is a chaperone-dependent E3 ligase that ubiquitylates unfolded protein. EMBO Reports. 2001; 2:1133-1138. [PubMed: 11743028]

5. Xu W, Marcu M, Yuan X, Mimnaugh E, Patterson C, Neckers L. Chaperone-dependent E3 ubiquitin ligase CHIP mediates a degradative pathway for c-ErbB2/Neu. Proc Nat Aca Sci. 2002; 99:1284712852.

6. Biamonte MA, Van de Water R, Arndt JW, Scannevin RH, Perret D, Lee WC. Heat Shock Protein 90: Inhibitors in Clinical Trials. J Med Chem. 2009; 53:3-17.

7. Brandt GEL, Blagg BSJ. Alternate strategies of Hsp90 modulation for the treatment of cancer and other diseases. Curr Top Med Chem. 2009; 9:1447-1461. [PubMed: 19860731]

8. Csermely P, Schnaider T, So "' ti C, Prohaszka Z, Nardai G. The 90-kDa Molecular Chaperone Family: Structure, Function, and Clinical Applications. A Comprehensive Review. Pharmacol Therap. 1998; 79:129-168. [PubMed: 9749880]

9. Garcia-Carbonero R, Carnero A, Paz-Ares L. Inhibition of HSP90 molecular chaperones: moving into the clinic. Lancet Oncol. 2013; 14:e358-e369. [PubMed: 23896275]

10. Goetz MP, Toft DO, Ames MM, Erlichman C. The Hsp90 chaperone complex as a novel target for cancer therapy. Ann Oncol. 2003; 14:1169-1176. [PubMed: 12881371]

11. Holzbeierlein JM, Windsperger A, Vielhauer G. Hsp90: a drug target? Curr Oncol Rep. 2010; 12:95-101. [PubMed: 20425593]

12. Jego G, Hazoume A, Seigneuric R, Garrido C. Targeting heat shock proteins in cancer. Cancer Lett. 2013; 332:275-285. [PubMed: 21078542]

13. Jhaveri K, Taldone T, Modi S, Chiosis G. Advances in the clinical development of heat shock protein 90 (Hsp90) inhibitors in cancers. Biochim Biophy Acta. 2012; 1823:742-755.

14. Neckers L, Workman P. Hsp90 molecular chaperone inhibitors: are we there yet? Clin Cancer Res. 2012; 18:64-76. [PubMed: 22215907]

15. Patel HJ, Modi S, Chiosis G, Taldone T. Advances in the discovery and development of heat-shock protein 90 inhibitors for cancer treatment. Exp Op Drug Disc. 2011; 6:559-587.

16. Prodromou C. Strategies for stalling malignancy: targeting cancer's addiction to Hsp90. Curr Top Med Chem. 2009; 9:1352-1368. [PubMed: 19860736]

17. Sidera K, Patsavoudi E. HSP90 inhibitors: current development and potential in cancer therapy. Recent Pat Anticancer Drug Discov. 2014; 9:1-20. [PubMed: 23312026]

18. Trepel J, Mollapour M, Giaccone G, Neckers L. Targeting the dynamic HSP90 complex in cancer. Nat Rev Cancer. 2010; 10:537-549. [PubMed: 20651736]

19. Whitesell L, Lin NU. HSP90 as a platform for the assembly of more effective cancer chemotherapy. Biochim Biophy Acta. 2012; 1823:756-766.

20. Yamaki H, Nakajima M, Shimotohno KW, Tanaka N. Molecular basis for the actions of Hsp90 inhibitors and cancer therapy. J Antibiot. 2011; 64:635-644. [PubMed: 21811259]

21. Burlison JA, Neckers L, Smith AB, Maxwell A, Blagg BSJ. Novobiocin: redesigning a DNA gyrase inhibitor for selective inhibition of hsp90. J Am Chem Soc. 2006; 128:15529-15536. [PubMed: 17132020]

22. Bras GL, Radanyi C, Peyrat JF, Brion JD, Alami M, Marsaud V, Stella B, Renoir JM. New novobiocin analogues as antiproliferative agents in breast cancer cells and potential inhibitors of heat shock protein 90. J Med Chem. 2007; 50:6189-6200. [PubMed: 17979263] 
23. Burlison JA, Avila C, Vielhauer G, Lubbers DJ, Holzbeierlein J, Blagg BSJ. Development of novobiocin analogues that manifest anti-proliferative activity against several cancer cell lines. $\mathrm{J}$ Org Chem. 2008; 73:2130-2137. [PubMed: 18293999]

24. Cohen SM, Mukerji R, Samadi AK, Zhao H, Blagg BSJ, Cohen MS. Novel C-terminal Hsp90 inhibitor for head and neck squamous cell cancer (HNSCC) with in vivo efficacy and improved toxicity profiles compared with standard agents. Ann Surgical Oncol. 2011; 19:483-490.

25. Donnelly A, Blagg BSJ. Novobiocin and additional inhibitors of the Hsp90 C-terminal nucleotidebinding pocket. Curr Med Chem. 2008; 15:2702-2717. [PubMed: 18991631]

26. Donnelly AC, Mays JR, Burlinson JA, Nelson JT, Vielhauer G, Holzbeierlein J, Blagg BSJ. The design, synthesis, and evaluation of coumarin ring derivatives of the novobiocin scaffold that exhibit antiproliferative activity. J Org Chem. 2008; 73:8901-8920. [PubMed: 18939877]

27. Donnelly AC, Zhao H, Kusuma BR, Blagg BSJ. Cytotoxic sugar analogues of an optimized novobiocin scaffold. Med Chem Commun. 2010; 1:165-170.

28. Eskew JD, Sadikot T, Morales P, Duren A, Dunwiddie I, Swink M, Zhang X, Hembruff S, Donnelly A, Rajewski RA, Blagg BS, Manjarrez JR, Matts RL, Holzbeierlein JM, Vielhauer GA. Development and characterization of a novel C-terminal inhibitor of Hsp90 in androgen dependent and independent prostate cancer cells. BMC Cancer. 2011; 11:468-485. [PubMed: 22039910]

29. Gunaherath GMKB, Marron MT, Wijeratne EMK, Whitesell L, Gunatilaka AAL. Synthesis and biological evaluation of novobiocin analogues as potential heat shock protein 90 inhibitors. Bio Med Chem. 2013; 21:5118-5129.

30. Huang YT, Blagg BSJ. A library of noviosylated coumarin analogues. J Org Chem. 2007; 72:3609-3613. [PubMed: 17328573]

31. Kusuma BR, Duerfeldt AS, Blagg BSJ. Synthesis and biological evaluation of arylated novobiocin analogs as Hsp90 inhibitors. Bio Med Chem Lett. 2011; 21:7170-7174.

32. Kusuma BR, Zhang L, Sundstrom T, Peterson LB, Dobrowsky RT, Blagg BSJ. Synthesis and evaluation of novologues as C-terminal Hsp90 inhibitors with cytoprotective activity against sensory neuron glucotoxicity. J Med Chem. 2012; 55:5797-5812. [PubMed: 22702513]

33. Marcu MG, Schulte TW, Neckers L. Novobiocin and related coumarins and depletion of heat shock protein 90-dependent signaling proteins. J Nat Cancer Inst. 2000; 92:242-248. [PubMed: 10655441]

34. Matthews SB, Vielhauer GA, Manthe CA, Chaguturu VK, Szabla K, Matts RL, Donnelly AC, Blagg BS, Holzbeierlein JM. Characterization of a novel novobiocin analogue as a putative Cterminal inhibitor of heat shock protein 90 in prostate cancer cells. The Prostate. 2010; 70:27-36. [PubMed: 19739131]

35. Shelton SN, Shawgo ME, Matthews SB, Lu Y, Donnelly AC, Szabla K, Tanol M, Vielhauer GA, Rajewski RA, Matts RL, Blagg BS, Robertson JD. KU135, a novel novobiocin-derived C-terminal inhibitor of the $90-\mathrm{kDa}$ heat shock protein, exerts potent antiproliferative effects in human leukemic cells. Mol Pharmacol. 2009; 76:1314-1322. [PubMed: 19741006]

36. Yu XM, Shen G, Neckers L, Blake H, Holzbeierlein J, Cronk B, Blagg BSJ. Hsp90 inhibitors identified from a library of novobiocin analogues. J Am Chem Soc. 2005; 127:12778-12779. [PubMed: 16159253]

37. Zhao, H., Blagg, BSJ. Inhibitors of Molecular Chaperones as Therapeutic Agents. Machajewski, T., Gao, Z., editors. Vol. 37. Royal Society of Chemistry; 2013. p. 259

38. Zhao H, Blagg BSJ. Novobiocin analogues with second-generation noviose surrogates. Bio Med Chem Lett. 2013; 23:552-557.

39. Zhao H, Donnelly AC, Kusuma BR, Brandt GE, Brown D, Rajewski RA, Vielhauer G, Holzbeierlein J, Cohen MS, Blagg BSJ. Engineering an antibiotic to fight cancer: optimization of the novobiocin scaffold to produce anti-proliferative agents. J Med Chem. 2011; 54:3839-3853. [PubMed: 21553822]

40. Zhao H, Yan B, Peterson LB, Blagg BSJ. 3-Arylcoumarin derivatives manifest anti-proliferative activity through Hsp90 inhibition. ACS Med Chem Lett. 2012; 3:327-331. [PubMed: 23316269]

41. Hatzivassiliou G, Haling JR, Chen H, Song K, Price S, Heald R, Hewitt JFM, Zak M, Peck A, Orr C, Merchant M, Hoeflich KP, Chan J, Luoh SM, Anderson DJ, Ludlam MJC, Wiesmann C, Ultsch 
M, Friedman LS, Malek S, Belvin M. Mechanism of MEK inhibition determines efficacy in mutant KRAS-versus BRAF-driven cancers. Nature. 2013; 501:232-236. [PubMed: 23934108]

42. Holderfield M, Deuker MM, McCormick F, McMahon M. Targeting RAF kinases for cancer therapy: BRAF-mutated melanoma and beyond. Nat Rev Cancer. 2014; 14:455-467. [PubMed: 24957944]

43. Diab S, Kumarasiri M, Yu M, Teo T, Proud C, Milne R, Wang S. MAP kinaseinteracting kinases emerging targets against cancer. Chem Biol. 2014; 21:441-452. [PubMed: 24613018]

44. Holzbeierlein J, Windsperger A, Vielhauer G. Hsp90: a drug target? Curr Oncol Reports. 2010; 12:95-101.

45. Whitesell L, Lindquist SL. HSP90 and the chaperoning of cancer. Nat Rev Cancer. 2005; 5:761772. [PubMed: 16175177]

46. Pratt WB. The role of heat shock proteins in regulating the function, folding, and trafficking of the glucocorticoid receptor. J Biol Chem. 1993; 268:21455-21458. [PubMed: 8407992]

47. Hadden MK, Lubbers DJ, Blagg BSJ. Geldanamycin, radicicol, and chimeric inhibitors of the Hsp90 N-terminal ATP binding site. Curr Top Med Chem. 2006; 6:1173-1182. [PubMed: 16842154]

48. Kobayashi N, Toyooka S, Soh J, Yamamoto H, Dote H, Kawasaki K, Otani H, Kubo T, Jida M, Ueno T, Ando M, Ogino A, Kiura K, Miyoshi S. The anti-proliferative effect of heat shock protein 90 inhibitor, 17-DMAG, on non-small-cell lung cancers being resistant to EGFR tyrosine kinase inhibitor. Lung Cancer. 2012; 75:161-166. [PubMed: 21767894]

49. Takezawa K, Okamoto I, Yonesaka K, Hatashita E, Yamada Y, Fukuoka M, Nakagawa K. Sorafenib inhibits non-small cell lung cancer cell growth by targeting B-RAF in KRAS wild-type cells and C-RAF in KRAS mutant cells. Cancer Res. 2009; 69:6515-6521. [PubMed: 19638574]

50. Sarbassov DD, Guertin DA, Ali SM, Sabatini DM. Phosphorylation and regulation of Akt/PKB by the rictor-mTOR complex. Science. 2005; 307:1098-1101. [PubMed: 15718470]

51. Sanchez-Laorden B, Viros A, Girotti MR, Pedersen M, Saturno G, Zambon A, Niculescu-Duvaz D, Turajlic S, Hayes A, Gore M, Larkin J, Lorigan P, Cook M, Springer C, Marais R. BRAF Inhibitors Induce Metastasis in RAS Mutant or Inhibitor-Resistant Melanoma Cells by Reactivating MEK and ERK Signaling. 2014; 7

52. Marusiak AA, Edwards ZC, Hugo W, Trotter EW, Girotti MR, Stephenson NL, Kong X, Gartside MG, Fawdar S, Hudson A, Breitwieser W, Hayward NK, Marais R, Lo RS, Brognard J. Mixed lineage kinases activate MEK independently of RAF to mediate resistance to RAF inhibitors. Nat Commun. 2014; 5:1-16.

53. Abel EV, Basile KJ, Kugel CH, Witkiewicz AK, Le K, Amaravadi RK, Karakousis GC, Xu X, Xu W, Schuchter LM, Lee JB, Ertel A, Fortina P, Aplin AE. Melanoma adapts to RAF/MEK inhibitors through FOXD3-mediated upregulation of ERBB3. J Clin Invest. 2013; 123:2155-2168. [PubMed: 23543055]

54. Carnahan J, Beltran PJ, Babij C, Le Q, Rose MJ, Vonderfecht S, Kim JL, Smith AL, Nagapudi K, Broome MA, Fernando M, Kha H, Belmontes B, Radinsky R, Kendall R, Burgess TL. Selective and potent Raf inhibitors paradoxically stimulate normal cell proliferation and tumor growth. Mol Cancer Ther. 2010; 9:2399-23410. [PubMed: 20663930]

55. Joshi M, Rice SJ, Liu X, Miller B, Belani CP. Trametinib with or without vemurafenib in BRAF mutated non-small cell lung cancer. PloS one. 2015; 10:e0118210. [PubMed: 25706985]

56. Nakamura A, Arita T, Tsuchiya S, Donelan J, Chouitar J, Carideo E, Galvin K, Okaniwa M, Ishikawa T, Yoshida S. Antitumor activity of the selective pan-RAF inhibitor TAK-632 in BRAF inhibitor-resistant melanoma. Cancer Res. 2013; 73:7043-7055. [PubMed: 24121489]

57. Hatzivassiliou G, Song K, Yen I, Brandhuber BJ, Anderson DJ, Alvarado R, Ludlam MJ, Stokoe D, Gloor SL, Vigers G, Morales T, Aliagas I, Liu B, Sideris S, Hoeflich KP, Jaiswal BS, Seshagiri S, Koeppen H, Belvin M, Friedman LS, Malek S. RAF inhibitors prime wild-type RAF to activate the MAPK pathway and enhance growth. Nature. 2010; 464:431-435. [PubMed: 20130576] 


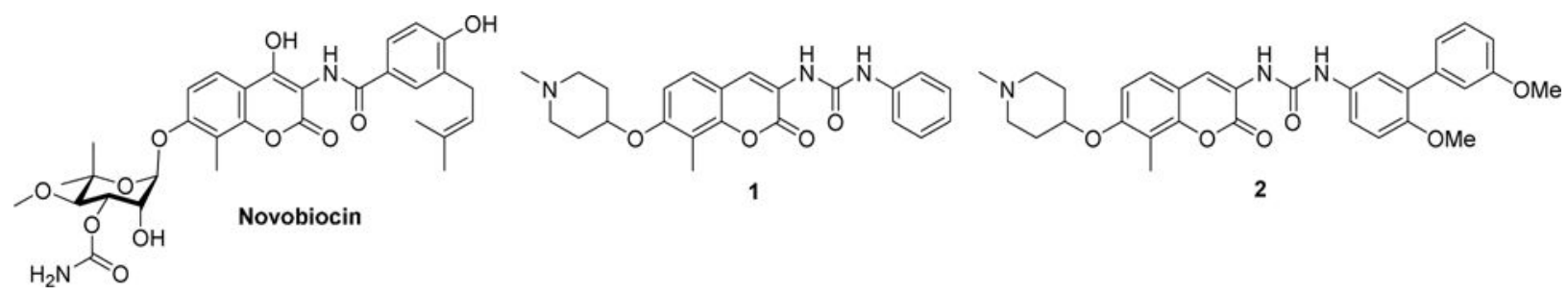

Figure 1.

Structures of novobiocin, compound $\mathbf{1}$ and $\mathbf{2}$. 
A

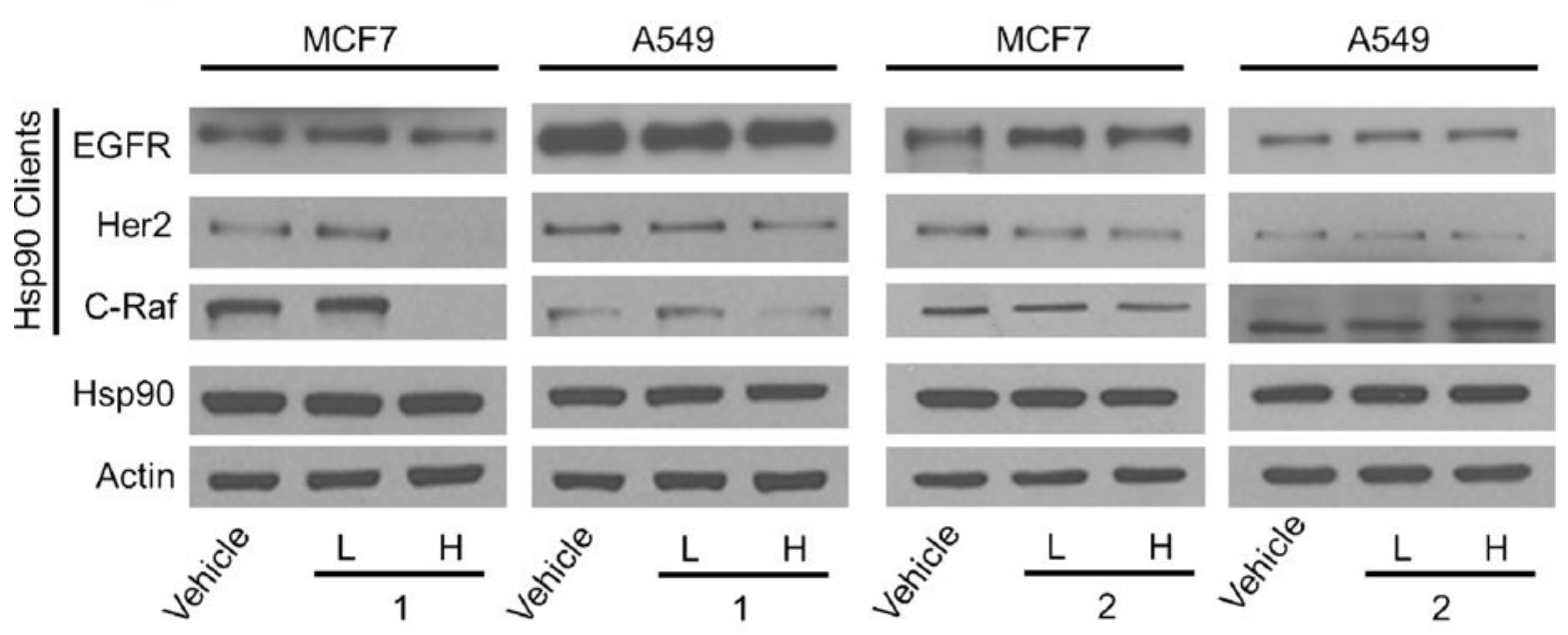

B

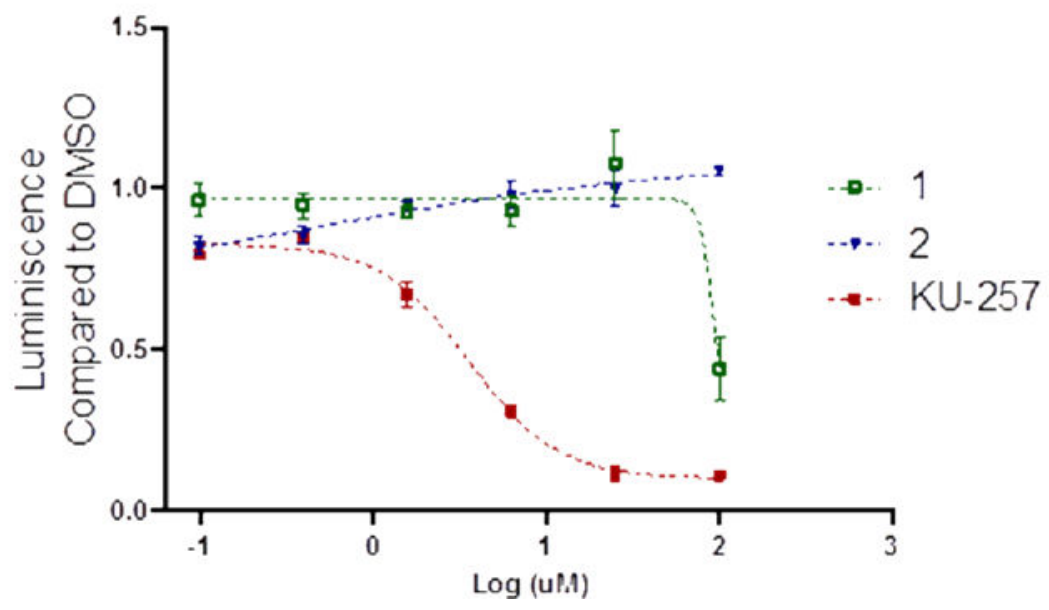

Figure 2.

(A) Western blot for Hsp90 client proteins (EGFR, Her2 and Raf) and Hsp90 using MCF7 and A549 cell lysates treated for 12 hours with vehicle ( $0.25 \%$ DMSO), a low concentration ( $\mathrm{L}$; half the IC50 value) or a high concentration ( $\mathrm{H}$; five-times the IC50 value) of compound 1 or 2 (B) The luciferase refolding activity of Hsp90 in PC3-MM2 cells with vehicle (DMSO), compounds 1 and 2, and the positive control, KU-257. The concentrations used were $0-100 \mu \mathrm{M}$. 

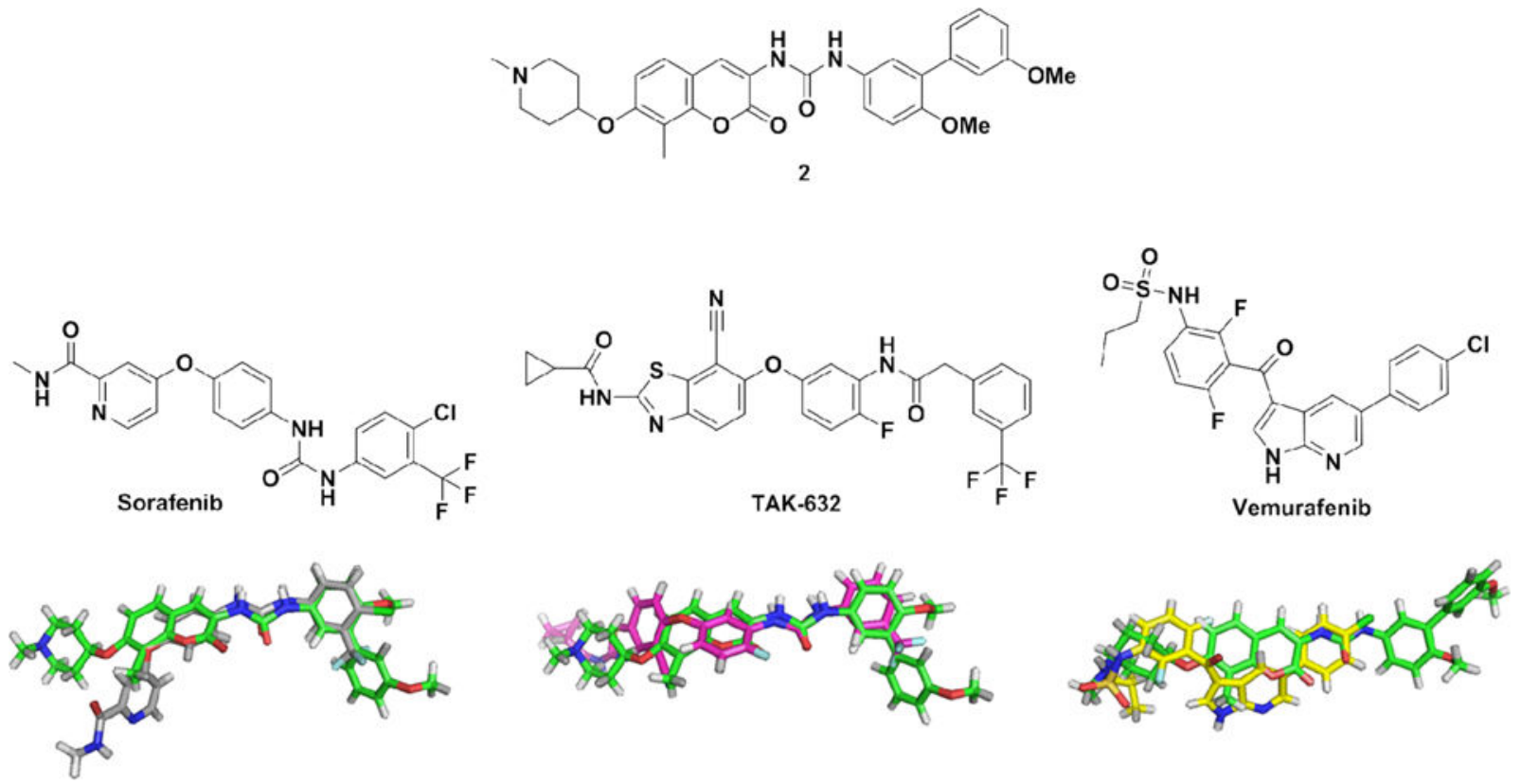

Figure 3.

Structures and the overlay of compound 2 (green) with sorafenib (gray; a kinase inhibitor that targets B-Raf and C-Raf), TAK-632 (magenta; a kinase inhibitor that targets C-Raf and wild-type B-Raf) and with vemurafenib (yellow; an inhibitor of mutant B-Raf). 


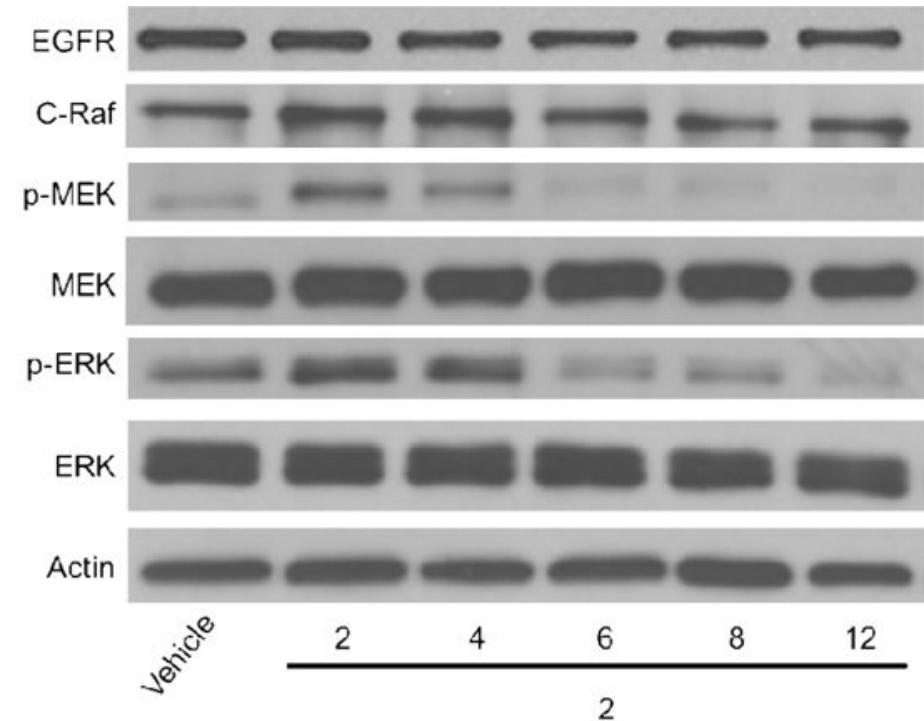

hours

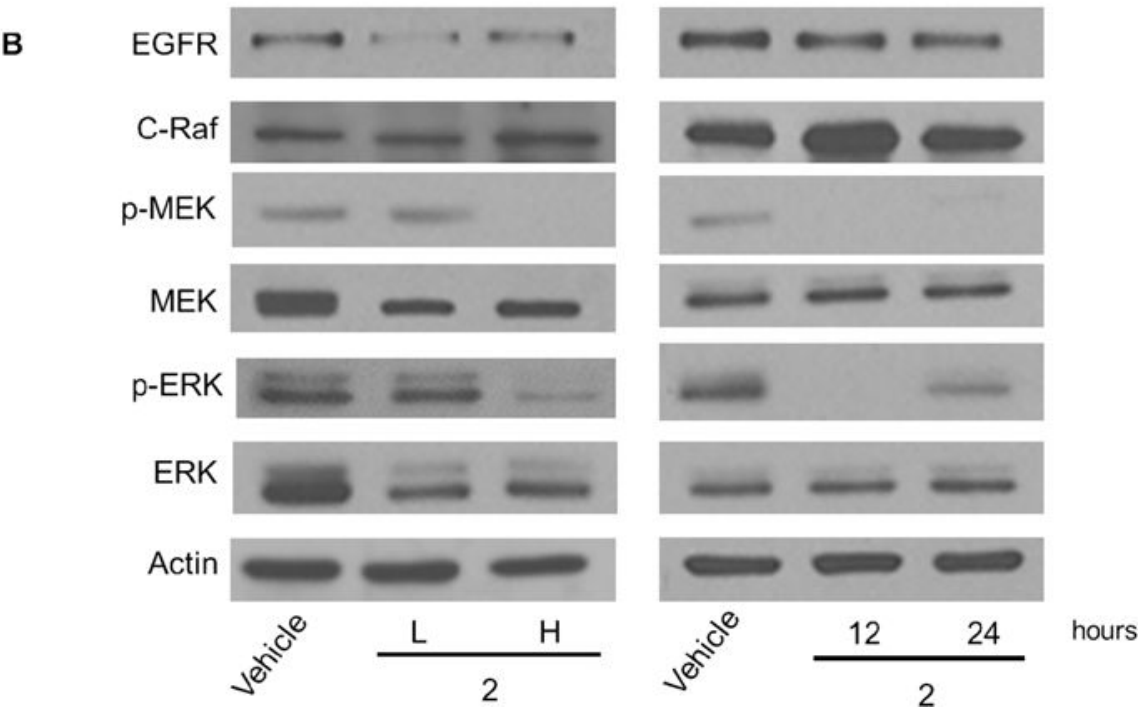

Figure 4.

(A) Western blot for proteins of the MAPK pathway (EGFR, C-Raf, MEK, ERK) and phosphorylated MEK and ERK (p-MEK and p-ERK) from A549 cell lysates treated for two to 12 hours with five times the $\mathrm{IC}_{50}$ value of 2 or vehicle $(0.25 \%$ DMSO) (B) Western blot for proteins of the MAPK pathway and phosphorylated MEK and ERK from A549 cell lysates treated for 12 or 24 hours with five-times the $\mathrm{IC}_{50}$ value of $\mathbf{2}$ or vehicle $(0.25 \%$ DMSO). 

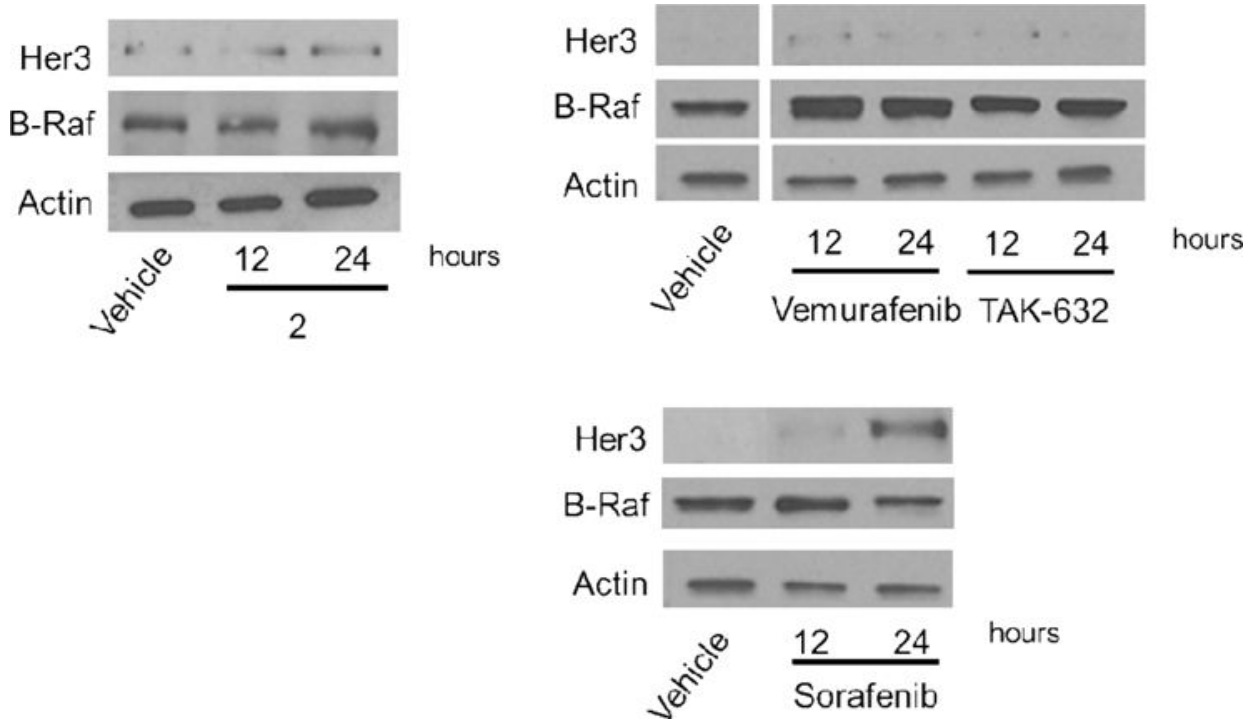

Figure 5.

Western blot for proteins Her3 and wild-type B-Raf from A549 cell lysates treated for 12 or 24 hours with five-times the $\mathrm{IC}_{50}$ value of $\mathbf{2}$, sorafenib, vemurafenib, TAK-632 or vehicle (0.25\% DMSO). 
A

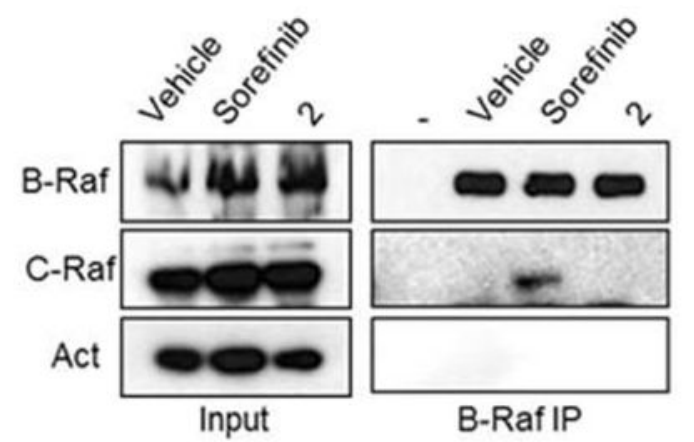

B

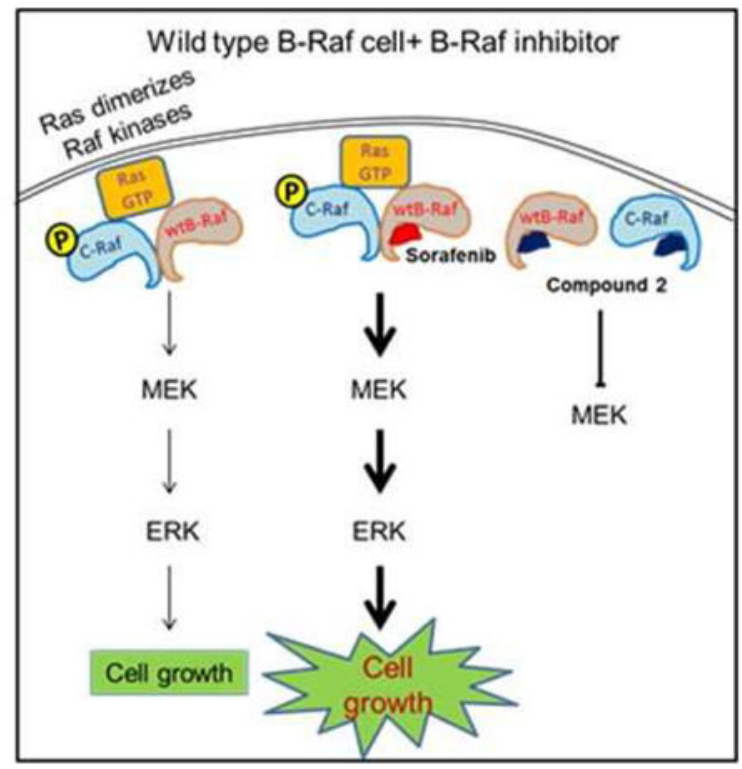

Figure 6.

A. Co-immunoprecipitation of B-Raf from A549 cell lysates treated for 24 hours with fivetimes the $\mathrm{IC}_{50}$ value of $\mathbf{2}$, sorafenib, or vehicle (0.25\% DMSO). B-Raf immunoprecipitated c-Raf in sorafenib treated cells, but not 2 treated cells. B. Proposed mechanism of action for compound $\mathbf{2}$ and sorafenib. In wild type B-Raf cells, basal level of B-Raf C-Raf dimerization occurs. In sorafenib treated cells, the B-Raf C-Raf dimerization is prevalent causing activation of the MAPK pathway, resulting in growth. In contrast, compound 2 prevents hetero-dimerization of B-Raf and C-Raf, and consequently, the MAPK pathway is not activated. 
A

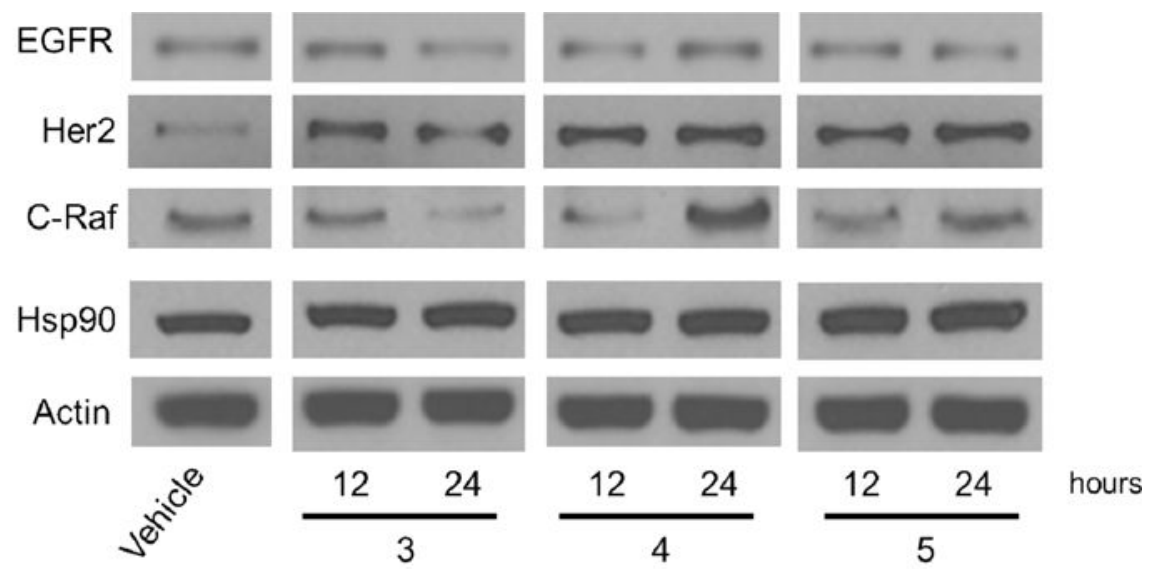

B
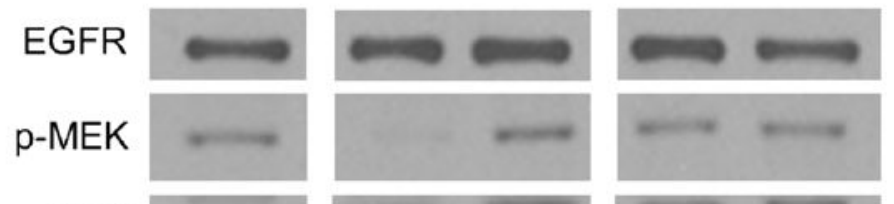

MEK
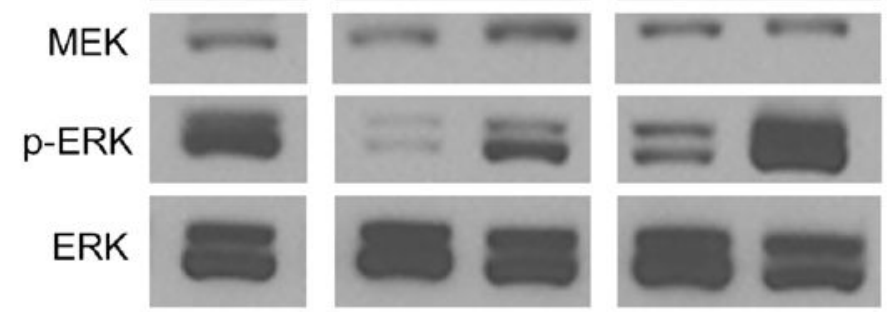

Actin
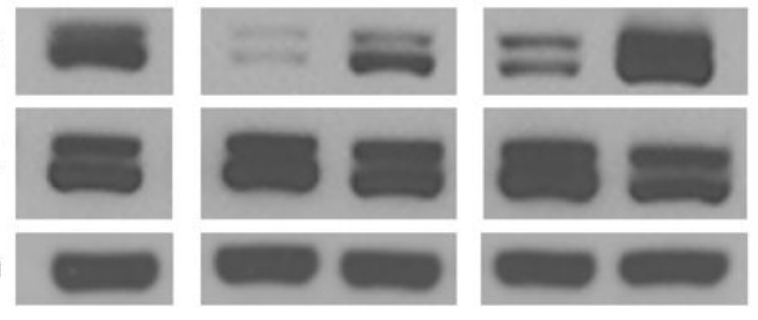<smiles>[C-][C+]=[Co]</smiles>
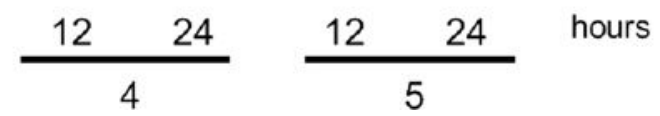

Figure 7.

(A) Western blot for Hsp90 client proteins (EGFR, Her2 and C-Raf) and Hsp90 using A549 cell lysates treated for 12 or 24 hours with a high concentration (five-times the IC50 value) of $\mathbf{3 , 4 , 5}$ or vehicle ( $0.25 \%$ DMSO). (B) Western blot for proteins of the MAPK pathway (EGFR, C-Raf, MEK, ERK) and phosphorylated MEK and ERK (p-MEK and p-ERK) from A549 cell lysates treated for 12 or 24 hours with five-times the $\mathrm{IC}_{50}$ value of $\mathbf{4 , 5}$ or vehicle (0.25\% DMSO). 

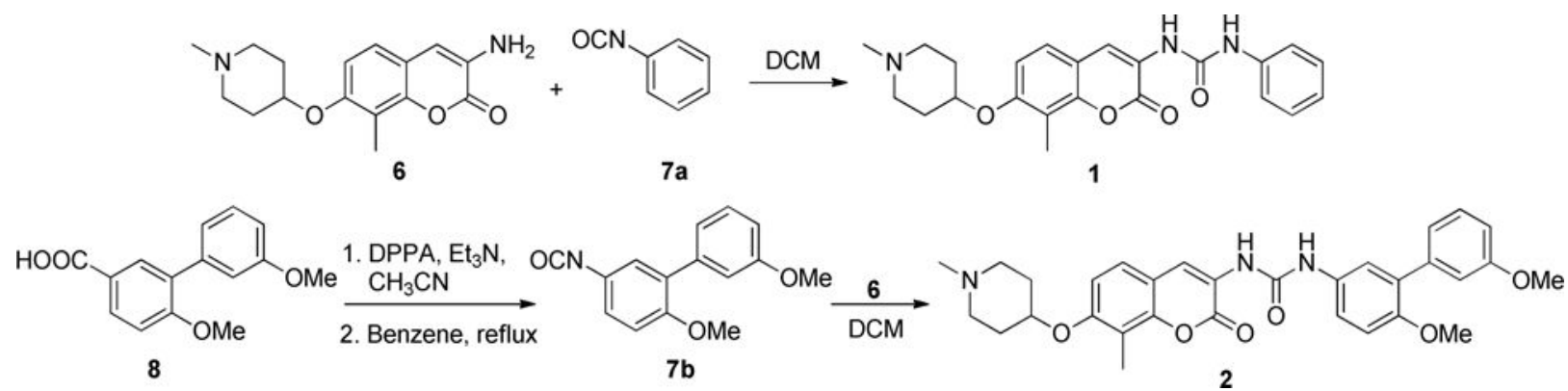

Scheme 1.

Synthesis of novobiocin-based urea analogs. 


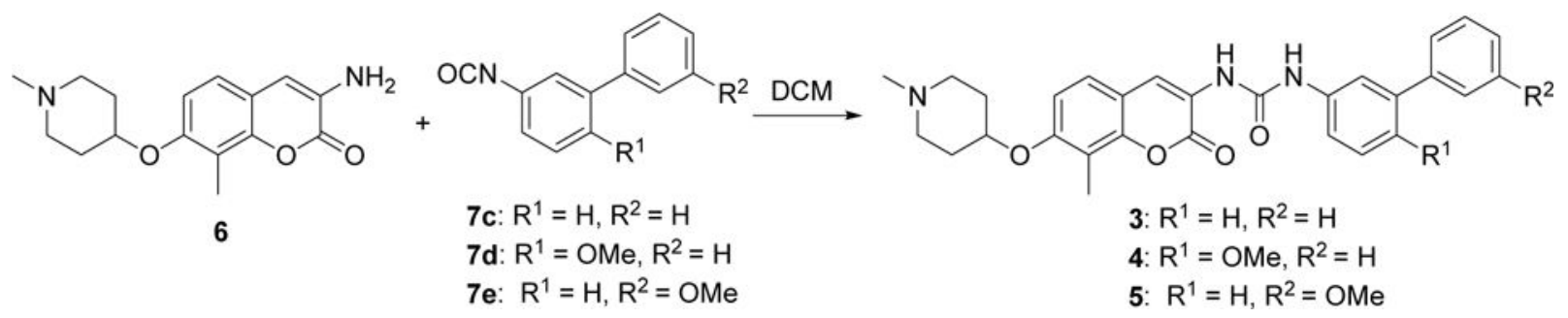

Scheme 2.

Continued synthesis of novobiocin-based urea analogs. 


\section{Table 1}

IC50 values determined for compounds 1 and 2 against the MCF7 and A549 cancer cell lines as well as the normal human cell line, MRC5.

\begin{tabular}{|c|c|c|}
\hline & \multicolumn{2}{|c|}{$\mathbf{I C}_{\mathbf{5 0}}$ Values $(\boldsymbol{\mu M})$} \\
\hline Cell Line & $\mathbf{1}$ & $\mathbf{2}$ \\
\hline MCF7 & $0.77 \pm 0.01$ & $0.17 \pm 0.07$ \\
\hline A549 & $0.24 \pm 0.00$ & $0.15 \pm 0.02$ \\
\hline MRC-5 & 3.6 & 4.3 \\
\hline
\end{tabular}


Table 2

IC50 values of compounds $\mathbf{3}, \mathbf{4}$ and $\mathbf{5}$ against the A549 lung cancer cell line.

\begin{tabular}{|l|l|}
\hline Compound & A549 Cell Line $\mathrm{IC}_{50}$ Values $(\mu \mathrm{M})$ \\
\hline
\end{tabular}

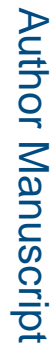

\begin{tabular}{|l|l|}
\hline $\mathbf{3}$ & $0.06 \pm 0.02$ \\
\hline $\mathbf{4}$ & $0.41 \pm 0.13$ \\
\hline $\mathbf{5}$ & $0.28 \pm 0.04$ \\
\hline
\end{tabular}

롤

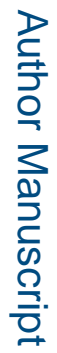

